をでふるん事在記はは薩 帶子て比な \&勤載先聞歑 び南宜較こあささゔき燒 又心し的とる机新及に は端少確は唯たた參ん關 此ひろ霬無此會かのでし 地邊 5な艻偝貝は方るて に部。而つ談西知でが在 他不而した加山ら あ然以 の便して樣妾貞なるし前 要なて部に字氏心か自に 件る又細訅とが。ら分二 が虎限な憶な本又其㤎回 あで摩るすつ會降記本本 る炶とるてのつ事會誌 序るのと。本諩てがにに に加生怯姴誌談四何入其 で産本称に會十時會訅 \& 特地誌る載它四頃し事 視別洁ににせ薩年如たが 察火諸紹此ら摩の何の揭 查摩りさ數た製當る明さ を筧御机年加造時人治れ すに存志間ど地然に四た る關じこにらの閶よ十こ

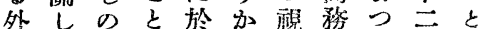

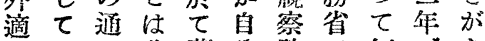
々重》先薩分談工何であ 薩大九ゔ魔とを、業ん會る 摩な州な燒し箴試な貝と 燒る地いにてさ驗とと云 の要のと關は机所をしふ 製務中云すそたにがて話 調薩若介處れ燒暮なは載

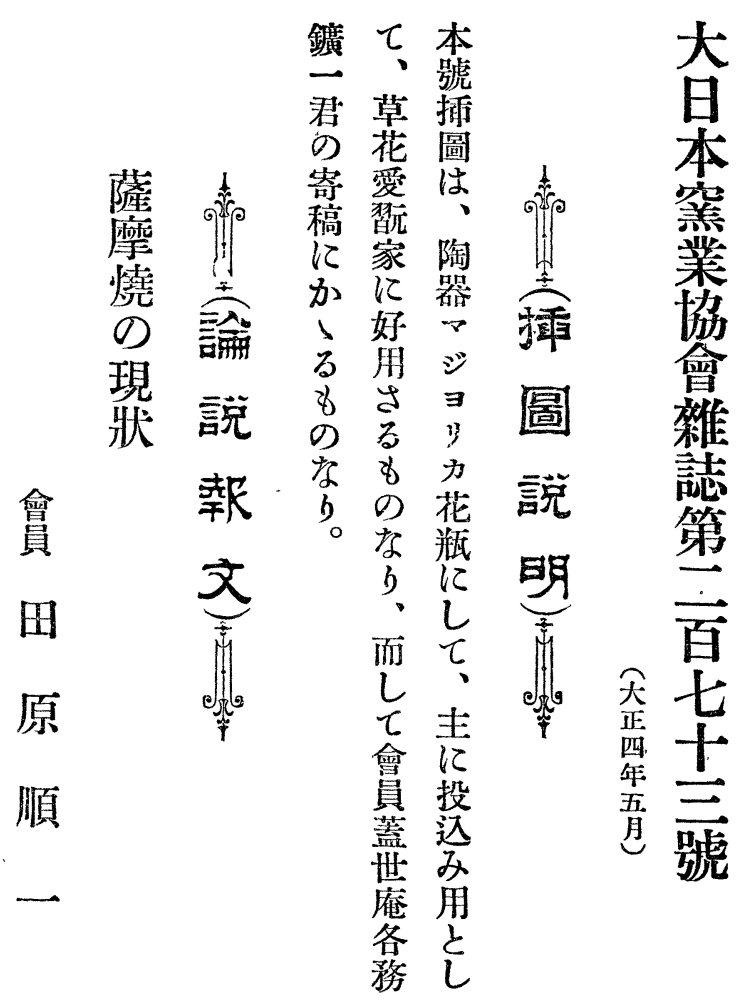

分存ででるを日名稱に始るのの慶薩

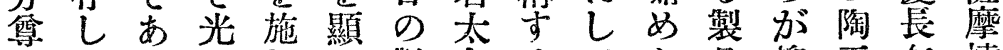
重てる淋しは製白るてれ品抑工年燒 さ居、模龍し造燒處其るは品間す

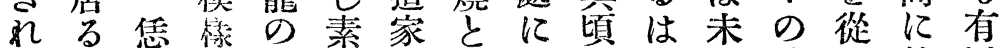

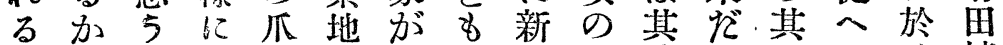
のらい見，の到稱れ製後粗濫こけ燒

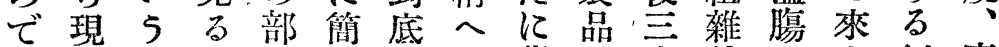

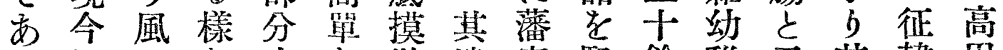

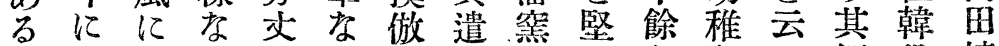

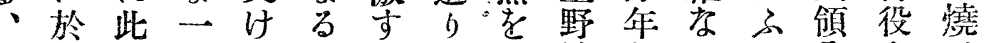
次て 㭙䶣に龍る口開燒をるべ内よ、

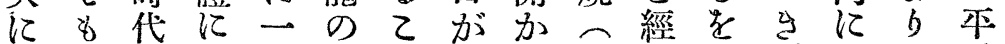

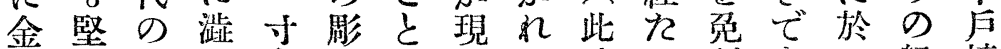

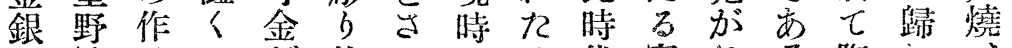
五. 㙄品て が物へのる代寬れ万陶述 彩とは然付な出製にに永ず）業國萩

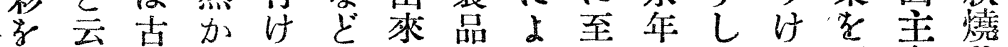
施 しばな雄あ之叫鹿島そと始津他

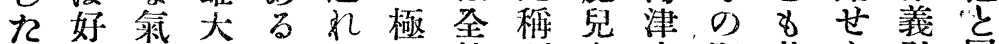
る古品㴊とに微然出島家漸其ら弘同 錦者の健云黑細相あ城久《當れ公じ

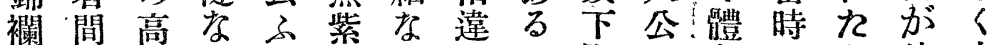

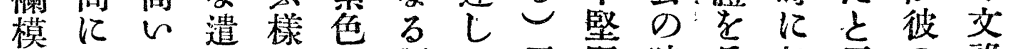

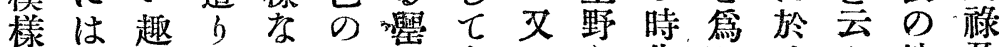

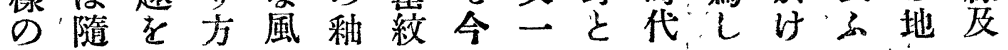

述のる 造 し方索牀 て 見のがを よ鹪 $\succ$ 見 5 め他度 - 2 に 思本 慗と 了、誌陶思

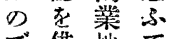
で 借 地 て まり の ช 境。玆樣現 に氣 時: 少輕 の しる壂 くに摩 現一㙄 今寸は 反出䔮 於撕々 けけ視 るる察 薩䛭 し 摩 紧 $\tau$ 燒 行 別 製 使 造. の 加利 狀 ら 篮 况之隹 を机安 叙等流 
し鹿か：製で術くで極汉其に者は方置今め間製

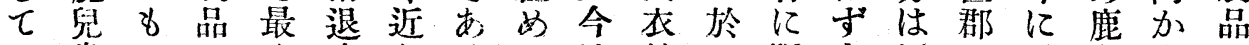
る島科の步年るれは鉢て販白近下於兒らは る市得意割し何、苗寄は为賣素年州て鸟は其

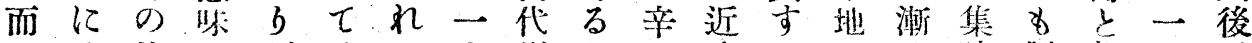

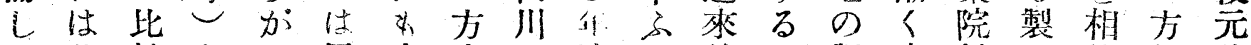
$\tau$ 此較を惡居疲鹿の波し餘の製襄村造俟伊祢

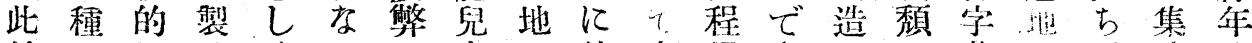
繪のに造くいは島。往東退あのの苗は院中

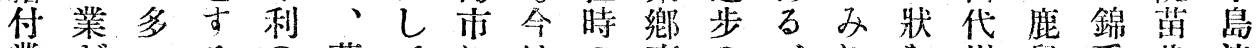
業がいるの薩てにはの壽の、にを川兒手代津 者一《，人薄摩る於名妙㢸跡業從呈と留の川吉

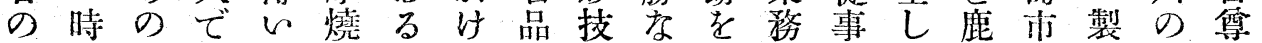
中にはあ古のがる傑をる示がし來兒を造陶公 で勃繪つの製然陶作揮人 $<$ 如之 $＼mathrm{~ 島 西 に 栄 の ~}$

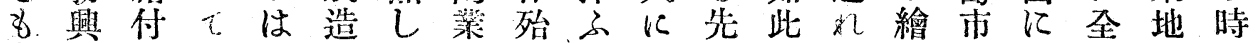
自し貶之素に苗家々に年沈付の去力に代 bて賣れ地從代はど由b各淪蝔業三るを於に 三其業に事川他趾なて工し兒は筃約洼て始 程數者反繪し程縣をく繼沈九岛現所四心它を

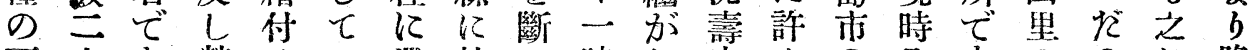
區十あ勞世手業於つ時れ官引の全あののれ降 別戶る少ざる務けて㶷た没で繪くる處てが

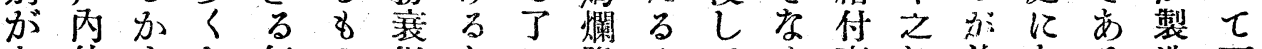
あ外 万し無の微とつ隆すてく專れ前ある造天 つに近て地〉し等九盛之以技門を者る、保 て達時然の內技しのを体畐業行の日現始年

な人と從擊遠と人薩子薩骨克る上在廻の素 どる云事を隔云士の酎商摩一る精にの方と地

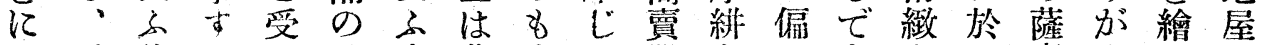
比鬼後るく地先藝出る肌とのあ抏摩宜付加

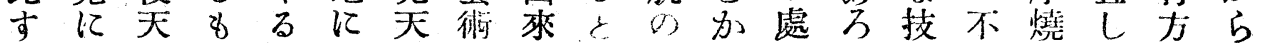
れ角的のに古的肌- - 特薩で5逨完はいの素 ば乙原加谌るのの向云產摩あがは全其處み地 其れ因一れ加原趣要及物芋る薩古不事加を 處をと般不ら因味領䅵をと加摩る囯業ら請購

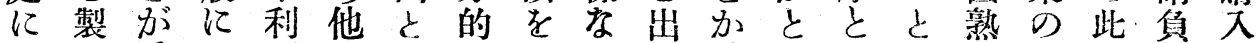

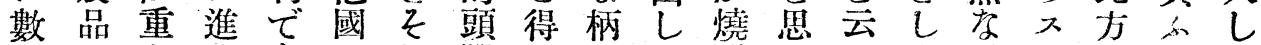

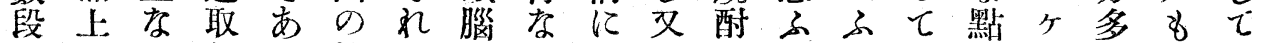

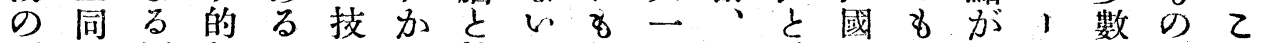

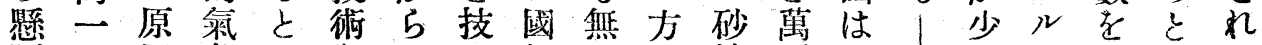
隔の因象云を此巧柄され糖更元|くの占のに が系をと子㕷の的でそは繪

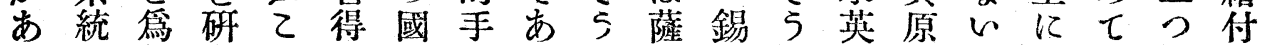
るにし究としは腕るな摩器で雄因|於るが

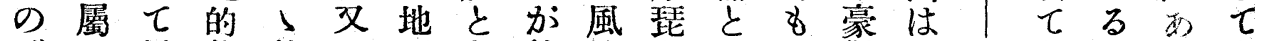
です居態他は理を然流琶吕存傑詮彫小、る自 あるる度に其上有しめと金くを索刻さ何が己

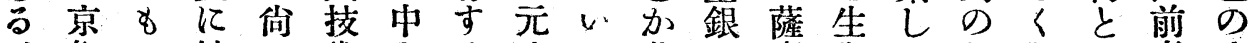
、都の缺一術冓る承九薩亡摩みれ如製云者店

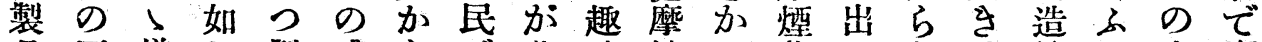

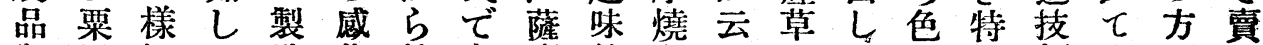

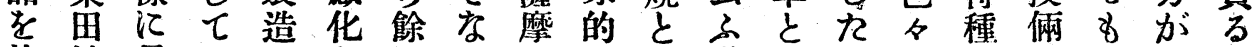

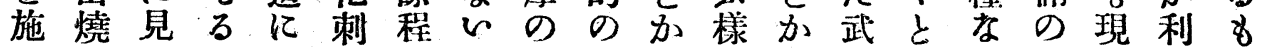


此み行ててのい具るる燒其燒でを泡れ゙以及橎

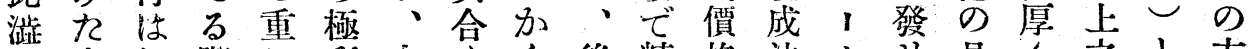

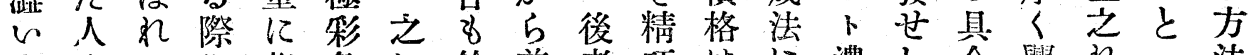

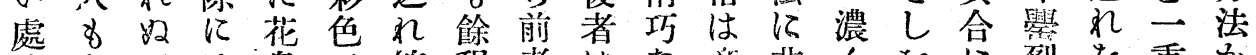

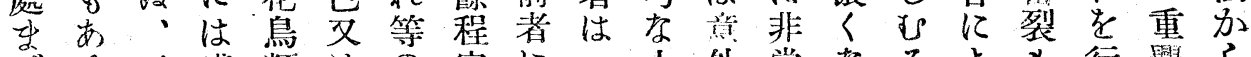

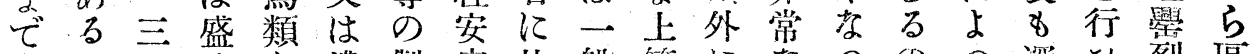

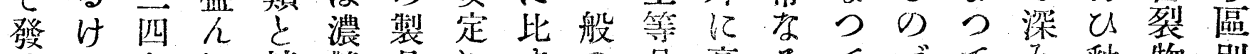

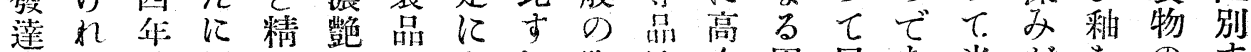
しど前緻細な放れ陶はく困居あ光がをのす

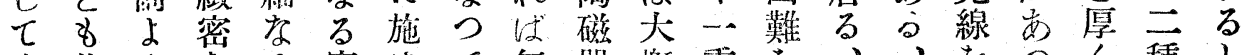

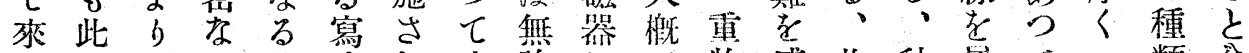

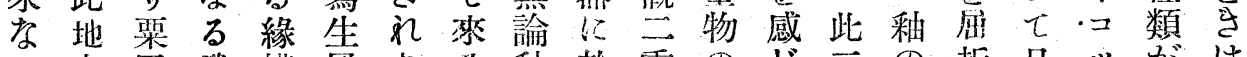
方田武模風れる釉於重のじ三の折且ッがは

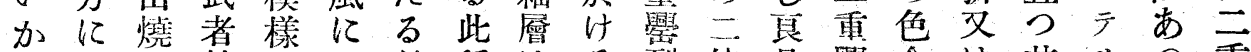
ら将に繪飞し繪種はる裂倍品學合は其りつ重

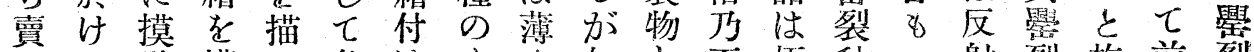

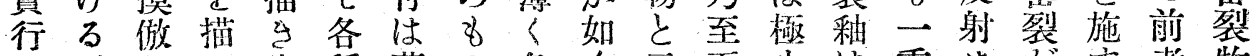
の需し $心$ 先種薩の色く云五少は重さ势者物 關要てた年の摩は合施及倍数甚物せ釉かは乞

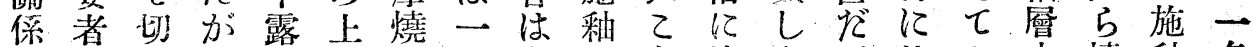
上の可此西繪獨般白はと達加不比 $キ$ 中燒粙名 此趣に風亞具得にく單にし得究ぶラに成吉御

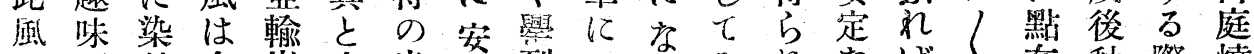

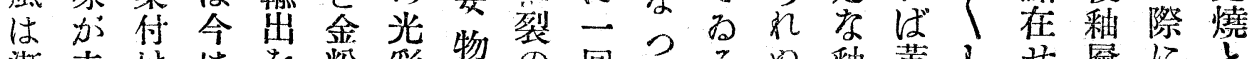

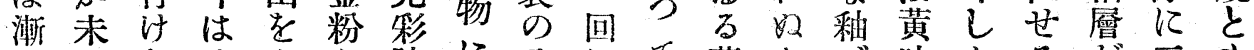

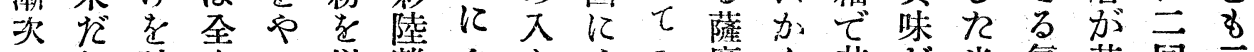
下如試々つ以離多b歨。摩 ら其が光氯甚回云

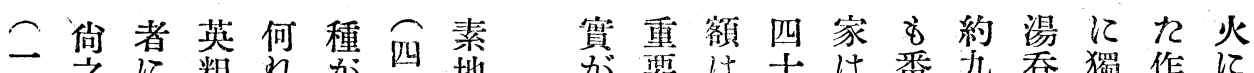

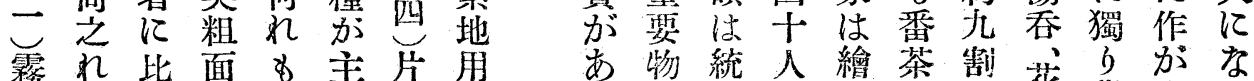

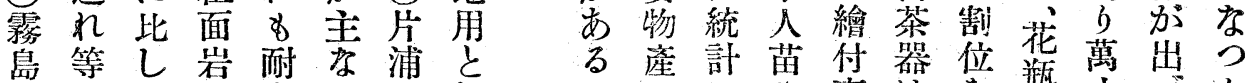

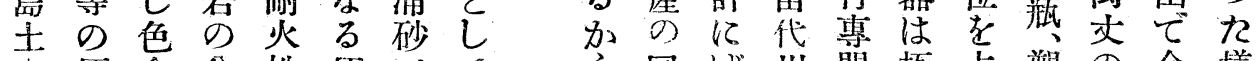

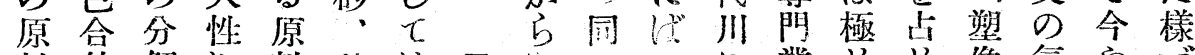

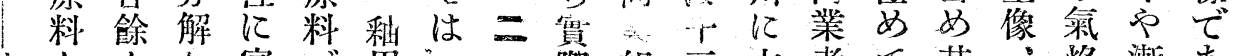

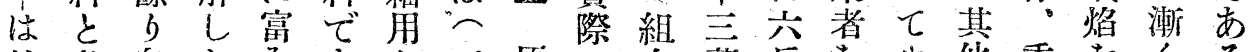

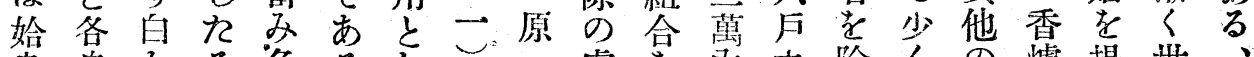
良自吕色るし霧處定內之除了の爐揚世

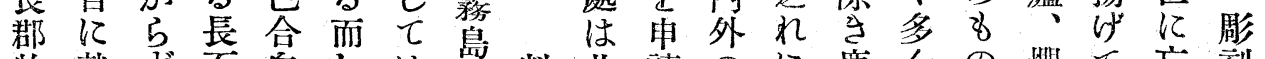

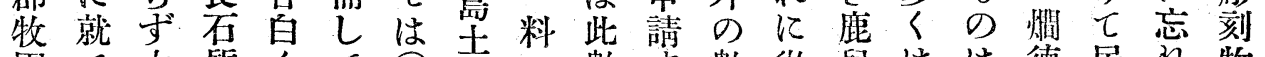
園て大質々て全主數守數從兒はは德居れ物 村更概の石之琶三怒䆘事息煎甚利るらは

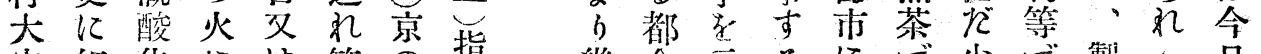
字細化には等合指幾合示るに年で製九 日

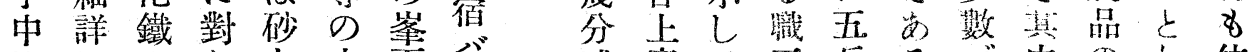
津にのしと中否

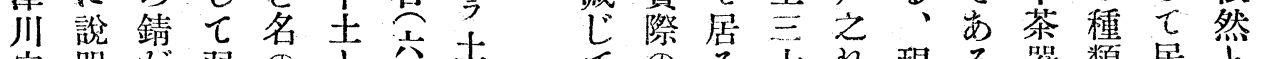

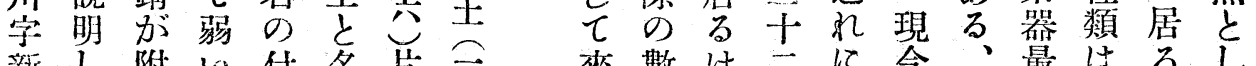

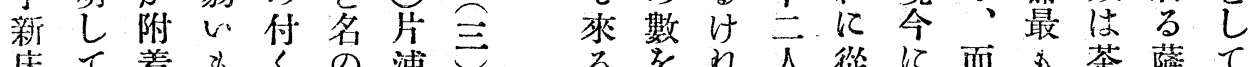

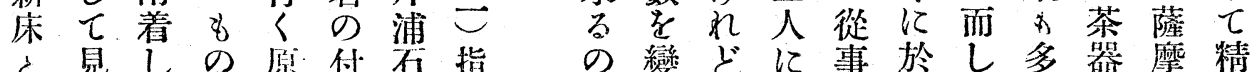

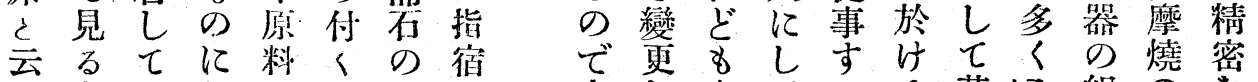

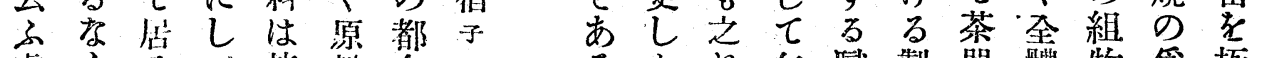
處らるて皆料合 即壮、前宆は兵土事は產工造での、め 


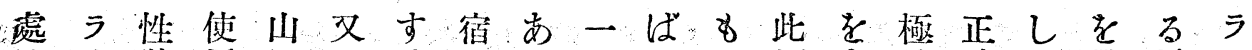
はは狀用に别る子るつーの原白め味い帶霧 チ

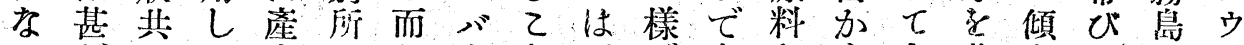

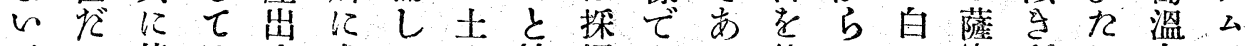

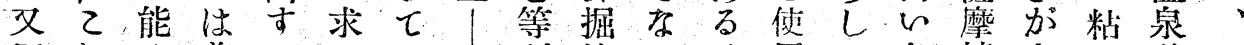

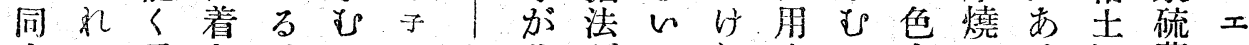
土に霧色けるバ此此がてれする合のるる黄 マ

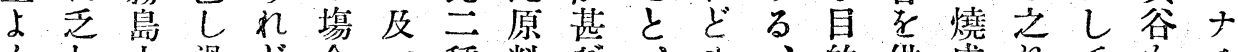

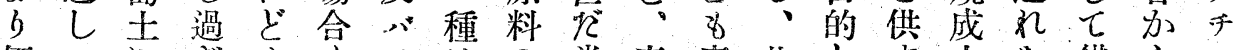

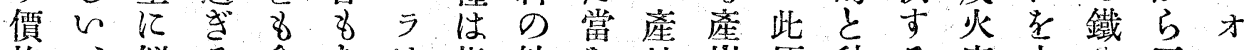
格、似る含あは指缺を地出原橎る度水分引 ン

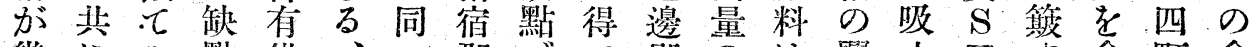

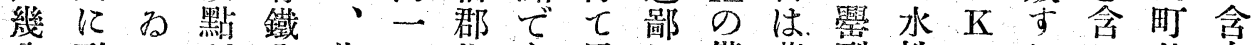
分耐㤩が分此の指あ居に僅薩裂性のれ气位有 廉火があ比附個缩るなし少摩をは 8 は 己距量

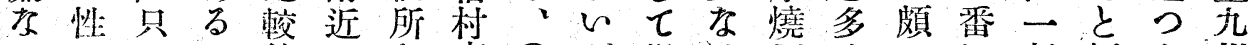
るに子、的二兄東二が過る原くるに割極れ州

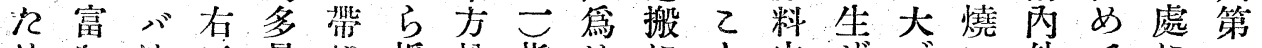
めむは二量に探松指めにと中ぜでい外てに一 苗乙可種孛此用厅缩に不、品しあての少産と 代と塑のる種す篗 バ價便品質さる見残く出云 川霧性原れ類るとう格な質最る、 る 㳯稍卞る

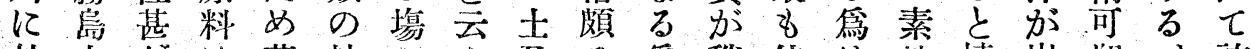
於土たは薩粘合々及及爲稍佳め地燒出塑、誇 $\tau$ 亿强其摩土8 處三不め8 良にの締る 性淡?

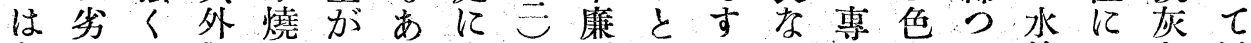

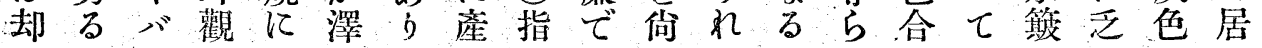

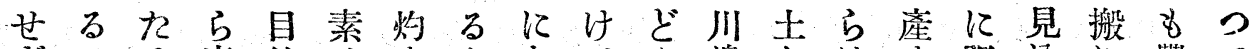
ずける 産的地す 又れる出にのれ殆る粒硅郡稱彼る出の頢此 耐どの方使可ばんけ々砂西しの耐しあ至に兩 火元にる角塑能どれ ので加て 新火てる極し原 性乙し、卞性く可ど，砂は世㖨潟性居原便七料

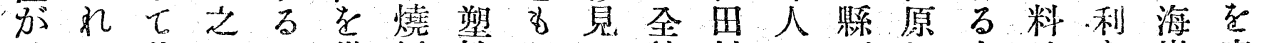
餘与其风、幾締性運れ然村の下料人地尔岸素

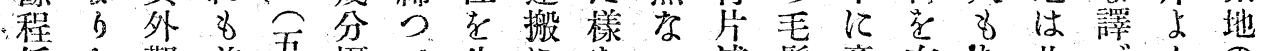

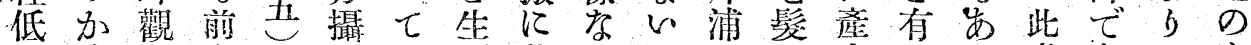
く遙は者京減極守甚狀のの存出丒り處市二主

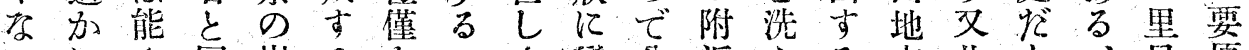
つにく同学るか乙く變分近ふる方此と、足原 て掔會じ石とにと不つ解推の蒲に處自桨ら料

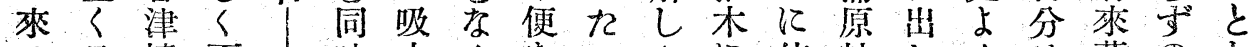

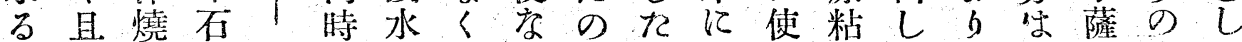
此つの 英川に性 $\mathrm{S}$ 點でる虐角土て二思摩處七

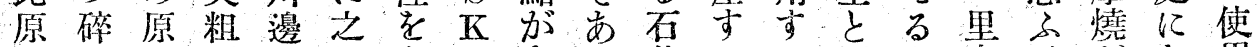
料粉料面郡狆存のある英るる。同人南、㤎あ用

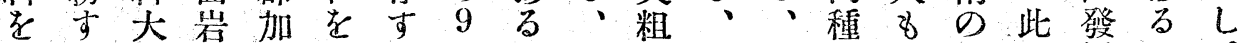

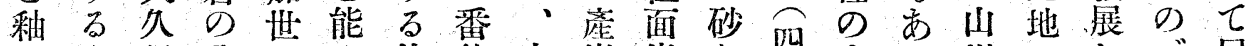
にす保分田く位位之出岩と四土る川のしで居

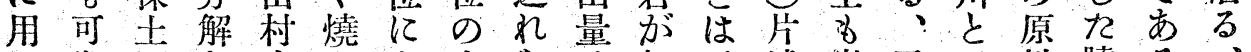

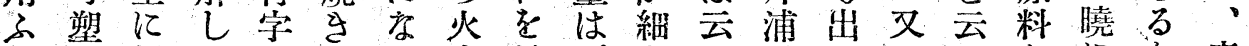

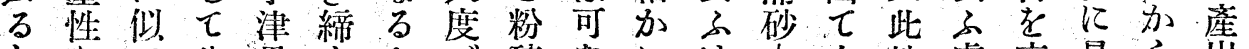
之老て 生“貫ら かで碎ないけ出地處京最ら出

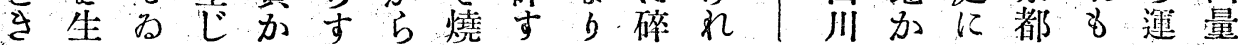




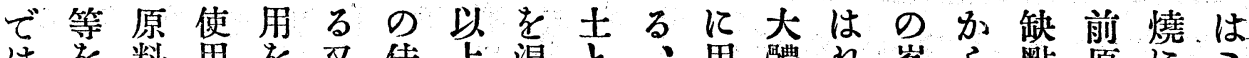

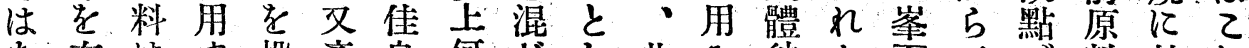

あ有は寸投產良何しし此る彼れ石云它料於れ

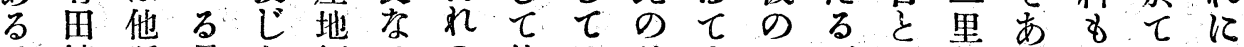

け燒縣量な何るの使は外京无石同位る 同は附

れのの茫くれ部原用附木の草英じ距、樣彼着

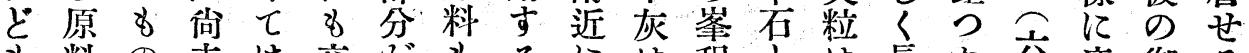

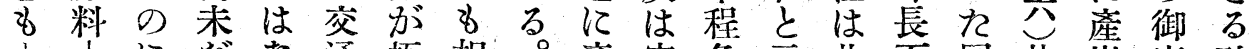

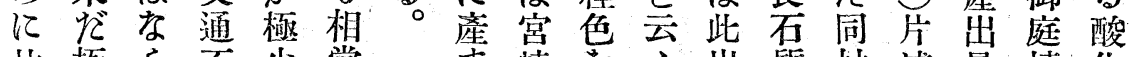

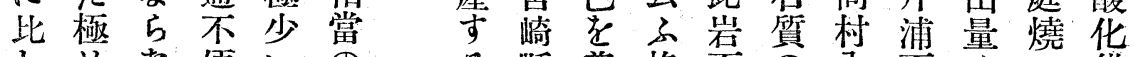

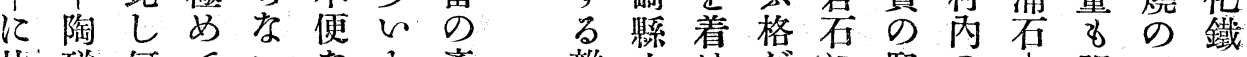

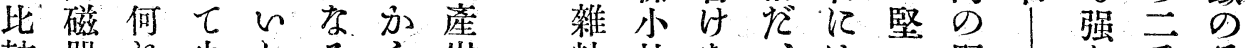
較器れ少しる ら出粘林な、は野、

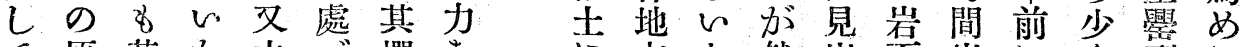
て原甚か之方撰を友方か.然出石獄にく裂に

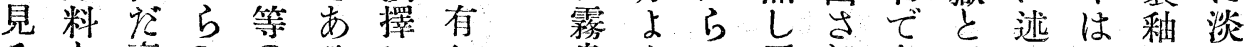

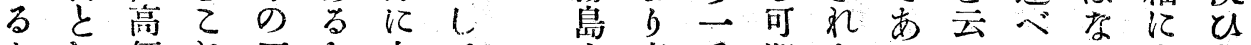

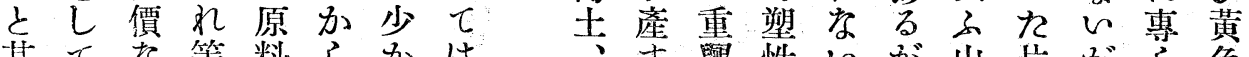

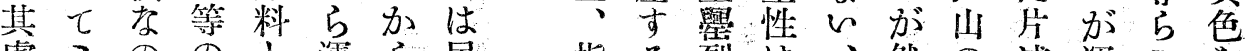

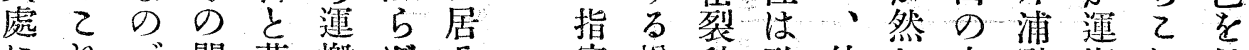
に㤂で關薩搬ざる 宿栖釉殆外し中砂搬れ呈 甚は市係摩に当

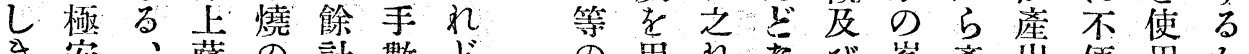

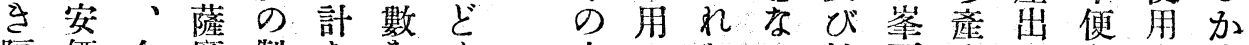

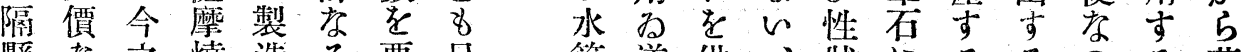

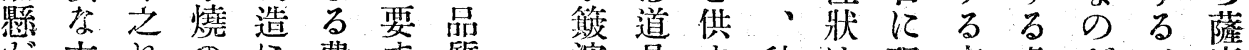

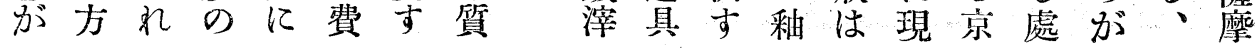

山對同无同搾修同同同泉栖片片京指指霧古

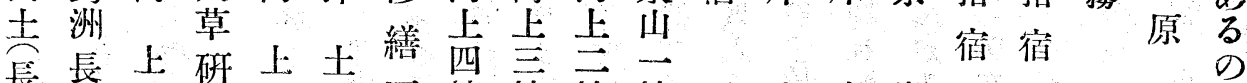

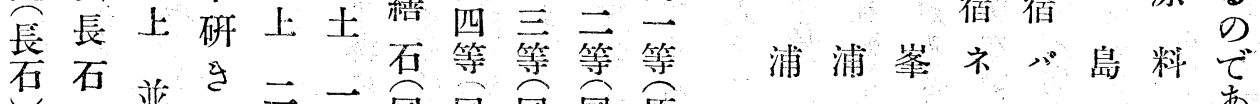

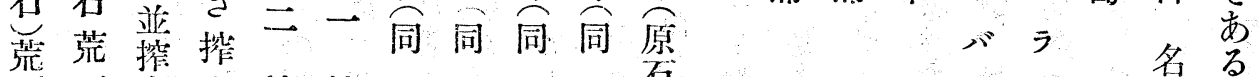
石石士上等等—石灰 砂石石土土土名方。

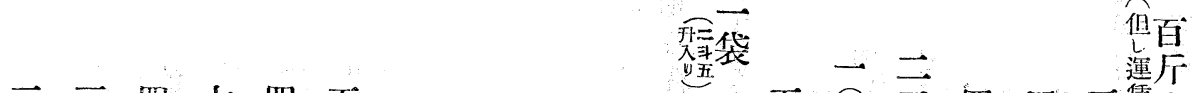

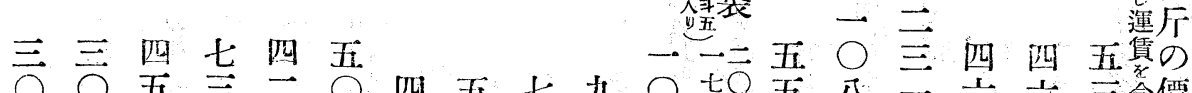

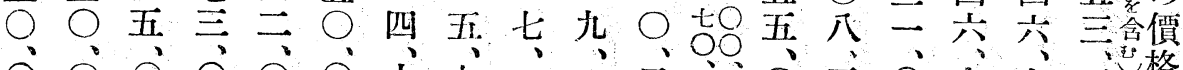
$000^{\circ} 0^{\circ} 0^{\prime}$ 六

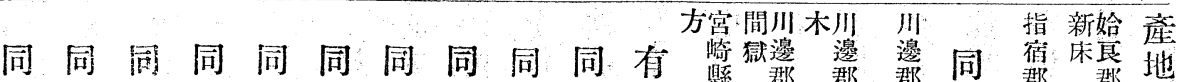

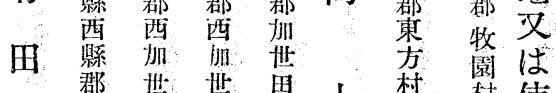
上上上上上上上上上上燒小思思村上 村 村使 地 野 椎 貫洼 梁地 て全の粉天 にし泉

同 袖素走碎草同用名岩同同同同素釉素同釉同同素用 にの地籍の $、$ 粉

用並水上上Ｌ碎

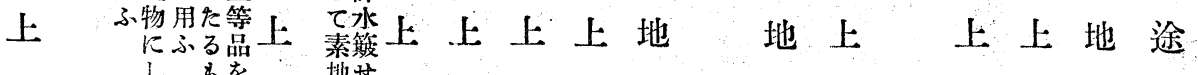




\begin{tabular}{|c|c|c|c|c|c|c|c|c|}
\hline \multicolumn{9}{|c|}{ 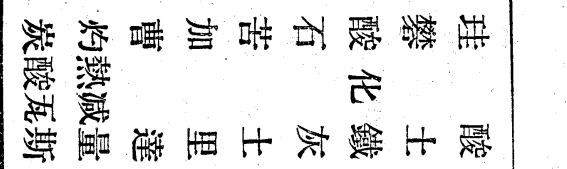 } \\
\hline ت्ञ & $\vec{\rho}$ & 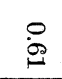 & $\begin{array}{l}\text { i } \\
\text { is }\end{array}$ & 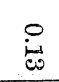 & & $\stackrel{0}{0}$ & $\begin{array}{l}\text { J } \\
\text { i } \\
\text { i }\end{array}$ & 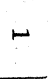 \\
\hline $\overrightarrow{0}$ & $i$ & 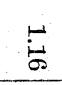 & $\begin{array}{l}0 \\
i 0 \\
0\end{array}$ & $\begin{array}{l}0 \\
\text { is } \\
\text { is }\end{array}$ & : & $\begin{array}{l}10 \\
0 \\
00 \\
0\end{array}$ & $\begin{array}{l}0 \\
\infty \\
\dot{0} \\
0 \\
0\end{array}$ & $N$ \\
\hline $\begin{array}{l}\overrightarrow{0} \\
\vec{*}\end{array}$ & 운 & $\stackrel{\circ}{\stackrel{P}{*}}$ & $\stackrel{0}{\dot{\sigma}}$ & i & 慗 & 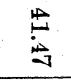 & $\begin{array}{l}\text { 虫 } \\
\text { 它 }\end{array}$ & $\omega$ \\
\hline 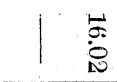 & 苑 & 悹 & $\stackrel{0}{\dot{H}}$ & P & i & ${ }_{\dot{s}}$ & $\stackrel{\vec{\infty}}{\infty}$ & $\mathbb{A}$ \\
\hline क्ष & 옹 & 总 & $\stackrel{P}{\not}$ & $\underset{\mathbb{N}}{P}$ & 繁 & 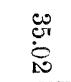 & 敢 & or \\
\hline 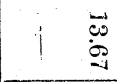 & $\underset{H}{\stackrel{i}{*}}$ & 엉 & 珤 & 通 & $\stackrel{\leftarrow}{\omega}$ & $\stackrel{0}{0}$ & $\stackrel{0}{:}$ & 0 \\
\hline 8 & $\stackrel{\overrightarrow{0}}{\dot{0}}$ & $\stackrel{\overrightarrow{8}}{8}$ & 임 & 옹 & 点 & 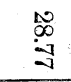 & $\underset{\infty}{N}$ & $\checkmark$ \\
\hline$\vec{B}$ & $\stackrel{\leftrightarrow}{\infty}$ & $\begin{array}{l}\infty \\
\dot{c o s} \\
\dot{\phi}\end{array}$ & : & Po & 車 & 苛 & $\underset{\vec{v}}{\vec{v}}$ & $\infty$ \\
\hline 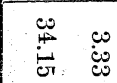 & نِّنِ & $\stackrel{-1}{-1}$ & No & $\stackrel{\leftrightarrow}{\stackrel{\leftrightarrow}{N}}$ & $\stackrel{\infty}{g}$ & $\stackrel{+}{6}$ & $\stackrel{\infty}{\stackrel{\leftrightarrow}{\oplus}}$ & 0 \\
\hline
\end{tabular}

げ結右柞匣木硅同石釉 る果耴

乙务述石上灰石

とな制篩 粉 粉石

古出原碎碎原范

る 号料灰土土物物石石

已 化 偆

不學 俵 三 五 至五 三二

得分 $\overline{0}$ 五 0 开五五

業 示 000000000

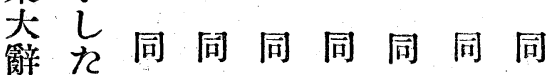

書 け

中 $h$

に記 ぞ 上上上上上上上

載生

せ惴

る最釉同坴同同同同

8 近

のの 道

分用上具上上上上 揭 析

\section{(1) 三異戶製七迄七粉類らて薩な他}

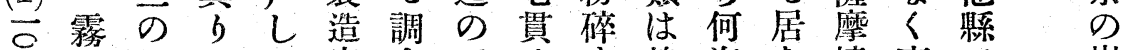

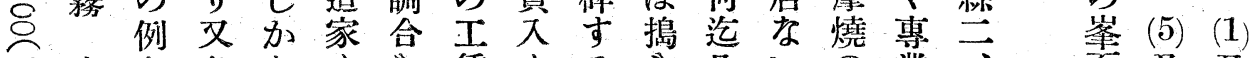

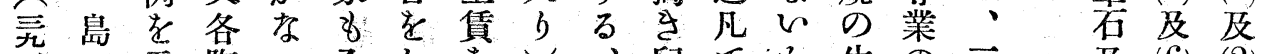

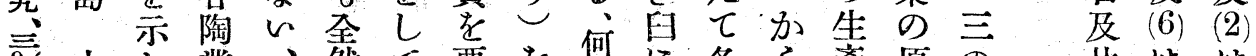

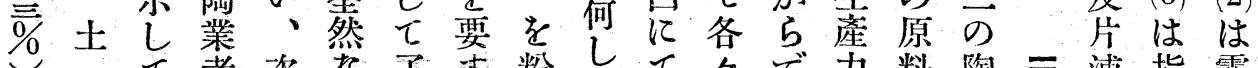

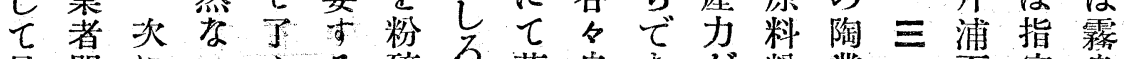
見間に心ふる碎頗荒自市が粉業一石宿島

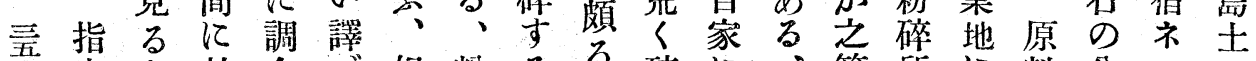

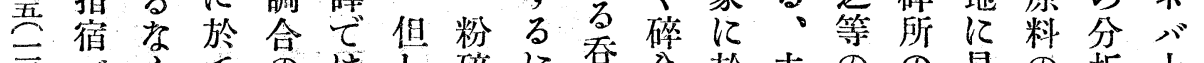

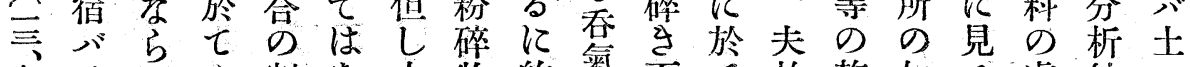

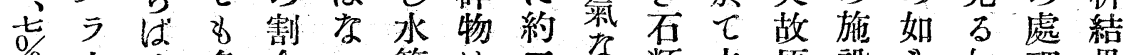

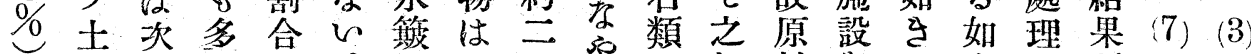

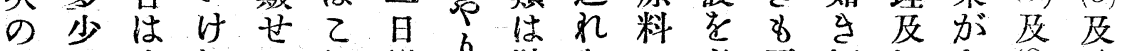
通の鹿风るれ掛步踏去の必更坏坏な (8) (4)

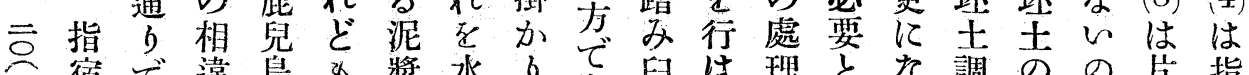

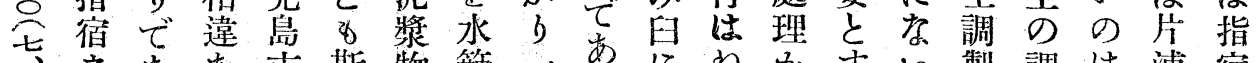

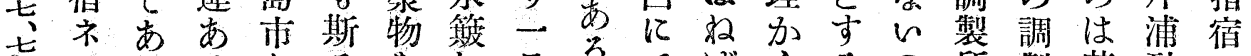

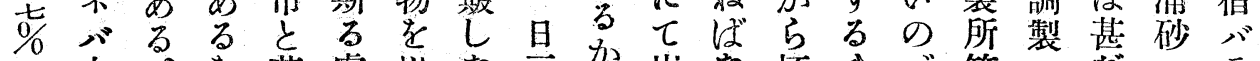

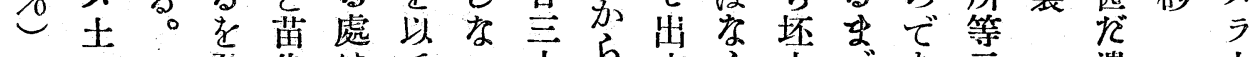
免代は思市

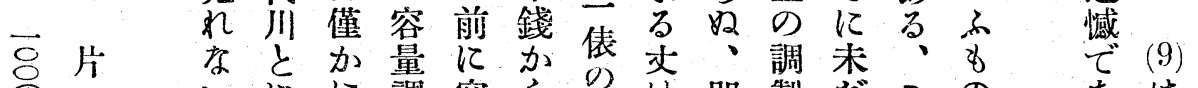

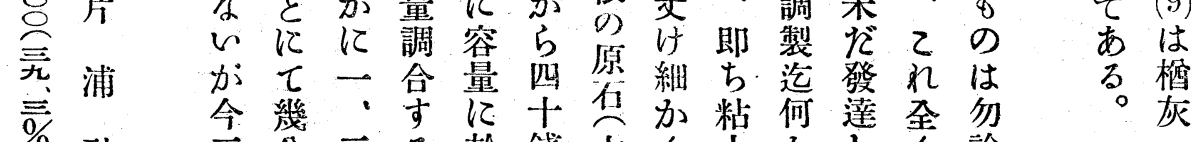

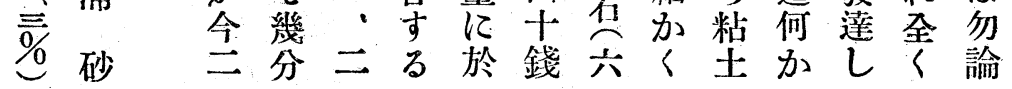


外水沈てづしるは大すめ索のと霧

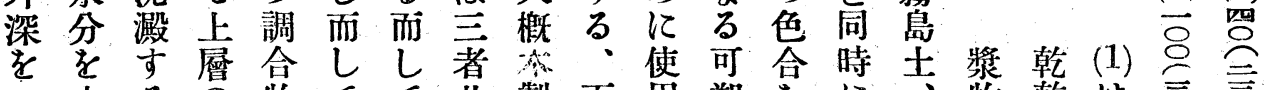

一去るの物てて共製而角塑艺飞物乾は至豆

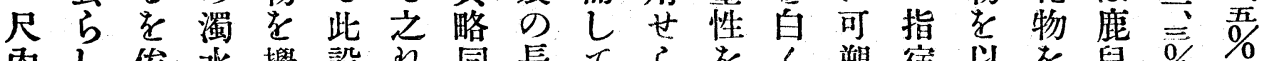

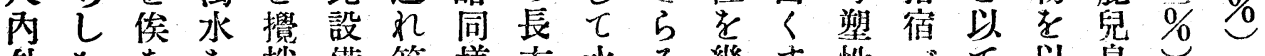

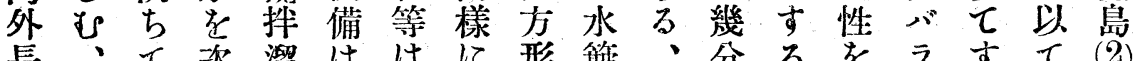

長、七炏溜ははに形鍍、分るをうす

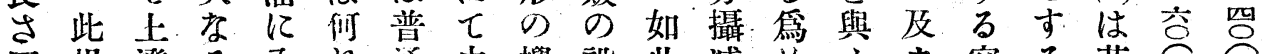

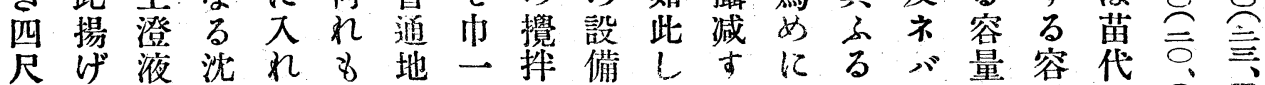

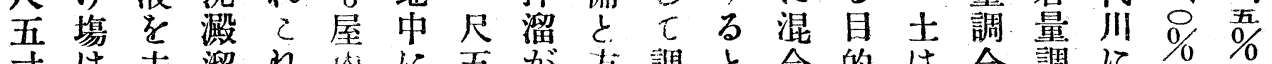

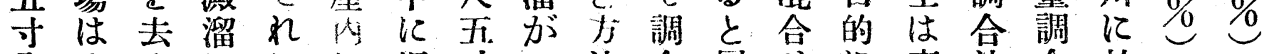

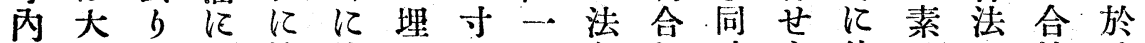

外概泥移蔐施め深つとし時

の屋漿し度し らさ沈はれ沉る角を 赤外のれの てる一澱他る素方世し

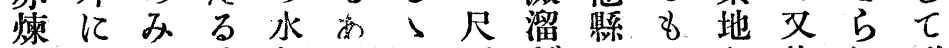
死設を後をるて五がにのを片れ耐 をり揚濁加、と元於は適浦特火 以ら将水人水李長つけ次度砂に性

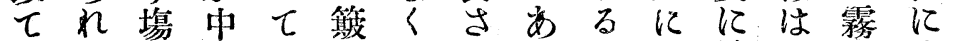

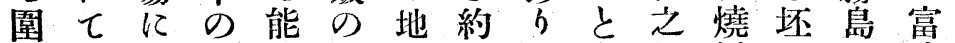
め巾移粘く方上四七天れ撑土土去 る三し土攪法に尺其美をらのはし

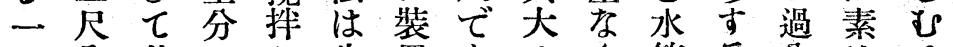
つ内其のし先置あさ、籍窟分地る

にな薩し木方嬏事を他其京 せ心摩さ灰栖京でにを引の泥の よ、燒るは市片行さ所漿峯

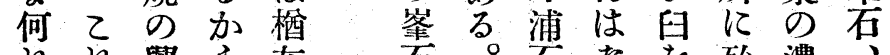

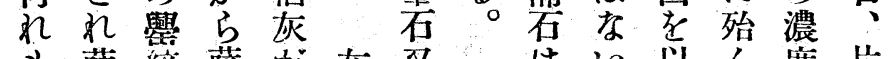

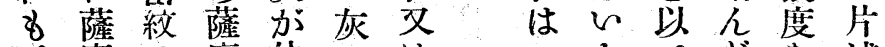
元摩は摩他は 來燒近燒の 片重ら細變一石

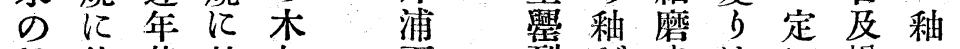
性 使甚於 灰 質角记て がす粗はは 釉る大此石 使原失係石 用 料 $L$ 上 $几$ しは外之比 七 觀れ 爽茨毁为幾 石損分 るに方使黄 整也る角味

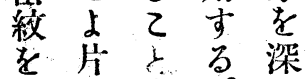
極浦少。台 《石く
石裂架は等は栖 釉一るなし灰 亿體處的容の調 使㳊薄而粉製 すいるし以し

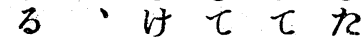
乙京れ調之る

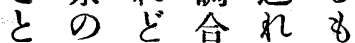
は峯敌等の 既石此江と てはの於調冬 前專地它合 にらに他すに ベ重ては乙䍌 方罪は之とし 通裂此れはて 叙兰於にる水
(3) る 塄 $\overline{0}$

は調豆

鹿 合引一 兒岛䍖 $\%$ に $\tau$

於 何

けn $\overline{8}$ る 的金四 水末音 箈淘 $\%$

了れ水少の は名を不角 多と除可形 的云资能夕 樣へ成でン でば形あり 四あ少にるで る己適かあ 方當占る。 こ度此 無 程 は揚 論度泥げ 尾に墏塲 濃至をに 地占素於 方し燒 程 嵞充 はるに分 な、移に 的坏 ᄂ 水 加土儿分 然の更を 乙 粘に除 有 性 餘々 田は分 乙 よ何のと 


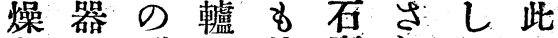
そ物でに特高市て地 防はあて意をれ以に

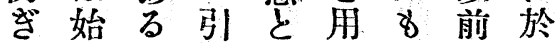
ま終即子专々 分此方上るるが此は 万繞小壮彼之重地蹴

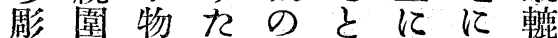
刻物にる精分之聘轤

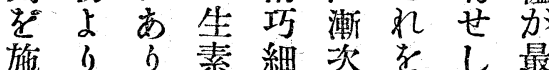
夺水 $\tau$ 地密盛便 $之 \ddot{~}$ 夜分はの学ん用と廣

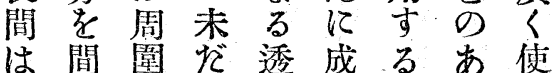
更接に乾しう樣る用 にに素燥欮てで京せ 此取地し多來あ都ら 上る土浮れるのれ

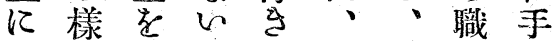
水に以間彫次近工轆

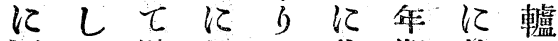
濡七壁於の薩塑就は せ素をて枝摩像 さ極 万地繞行術燒等七少 布のららは唹江養數 を乾し名輑最は成に

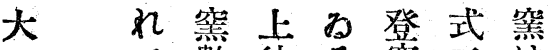
て數彼る篤等 口居艾の、管百 る 笠其中連年

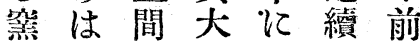

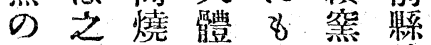
内办市何正補 容等筌構れ基助 一素少造加をの

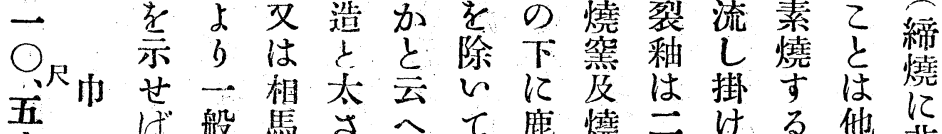
兵次航獁は堯は鹿兒成

の少の其尔他島 涌 $心$ 窟整型 世市

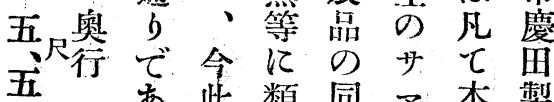
知同 。纪系古古所 於 $\tau$ 統 $心$ 乘に

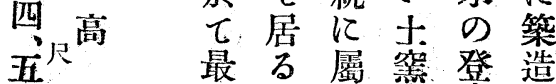

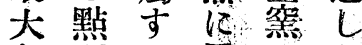

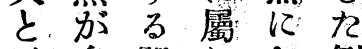
云多關しし倒 はく係てて 燋 やれはbる期洲の分樂 了は生現美任石代吕に 方長《今江粉名管生 で石極使させをにてせ あ及不用雤ず使殆粟し るは適せ称粟用ん田生 五と長當る老田しど燒る 云石宗釉生燒之長の㤎 成々にる用ぜの的石調如

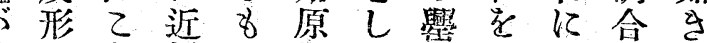

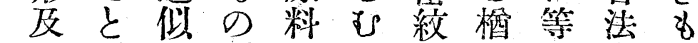
施汃世で柿るに灰しにの 釉確るあ薩乙優をる準で 定方名摩亡混彼じ

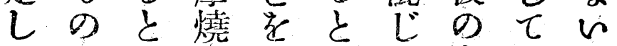

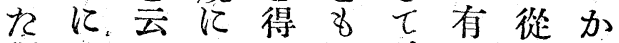
譯改了是九出試田來ら でむ乙非のと驗にので あると其でるし於京あ

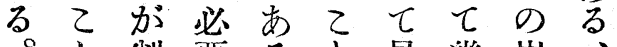

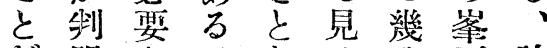
分明李、学分石論 最しる此己處使及よ 8 而繁結極加用はb 適し 校果微余せ片證 當七索に細のる浦據 な之現依な豫對石自

裂皆にに薩は枝筆て以 釉突小於摩一術を覆て

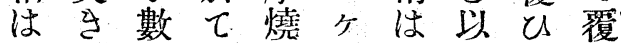
一込を之は月專て彫u 回及錦れ全內阴水刻乾

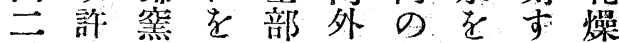
六重 $b$ 亿行素を職洗心㢳

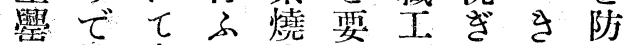

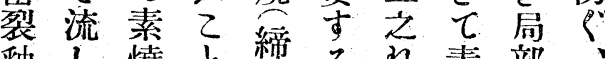
秞烓文燒るれ素部

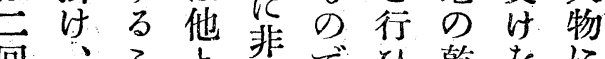

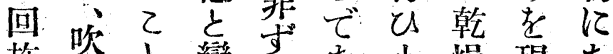
施吹變导市小燥現あ 釉掛は多る物夺はb し势あは专。にるして て等るなる、はのては 翻等尚而学枝全 厤行施只し 週防汪部 厚は急登少。施濡

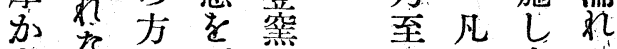

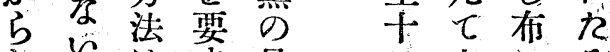
し心は卖最白之にる 巳一殆る後大れは布 る 重ん塲の物等時を 。霎と合室にの々以 

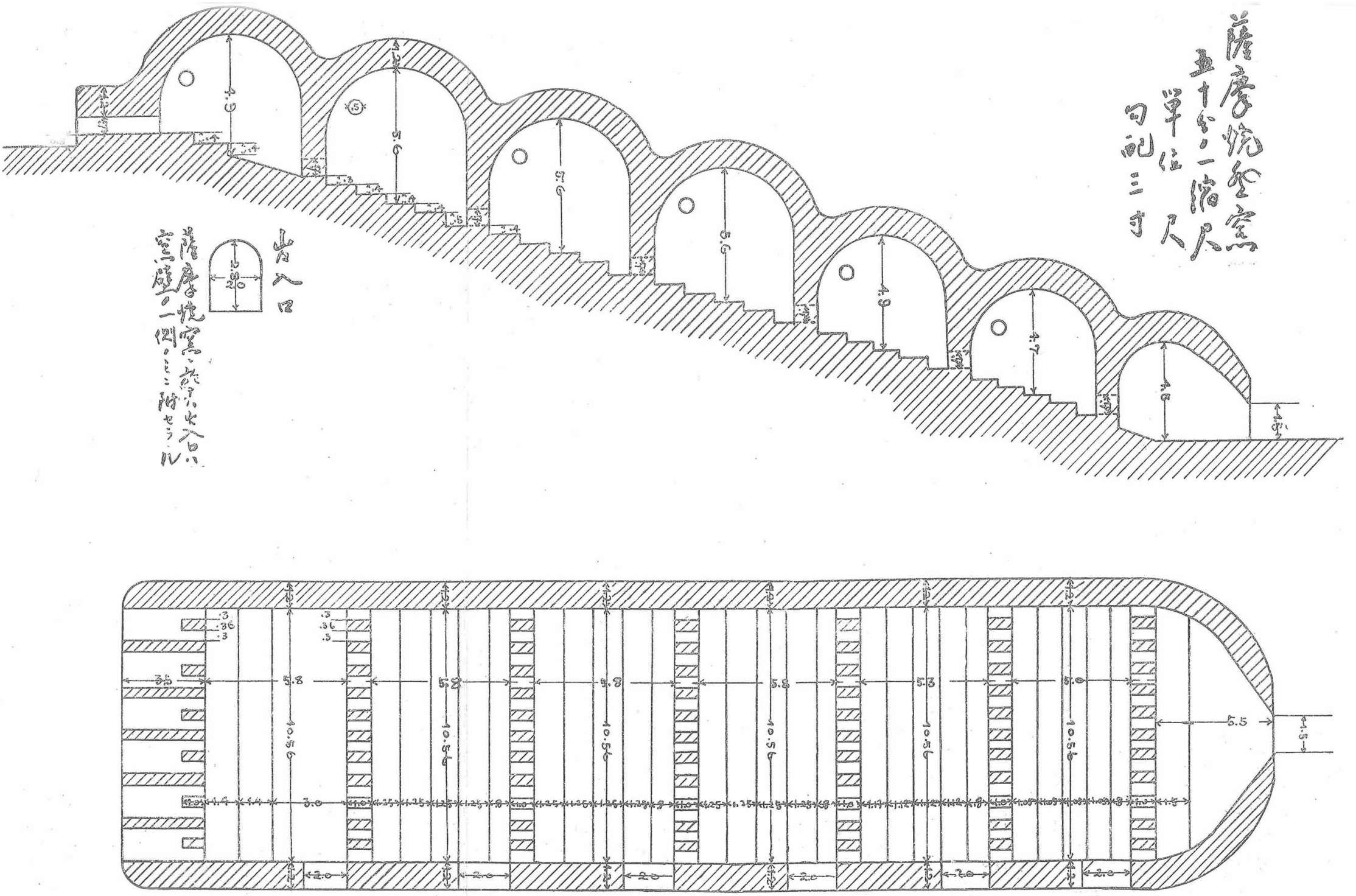


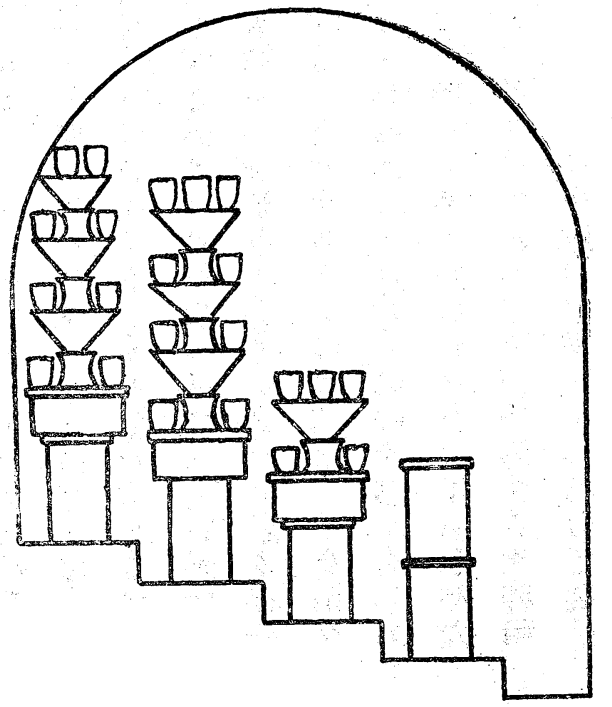

其る道づる說る此で辧而ふ䪪 上臺具窵な明積吞市字し極壁 にをと床らしみ匊る積て幼の 煎立䊈に怔て方極、多不稚一 茶宁高先見をむ今方經な侧
の 如 第第第第

橴勾室室室室室室 附茄配美

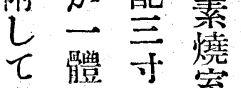

あ體寸室

る 小

次岕

に

筀

棓

崖五五五五五五。

所草公分分三0

天 材

科 投

積 入

会能四五舫四四 旮六六尤

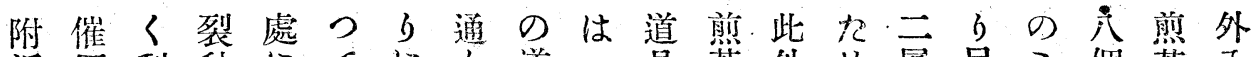

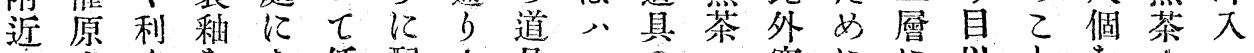

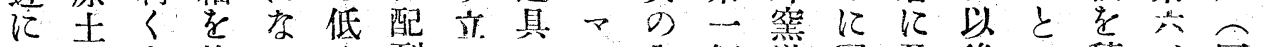
產乞處施るく列てののみ個道圖芚後こ皘、㕅

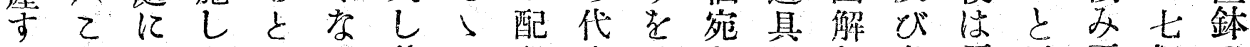
るれ置れ三其火凅

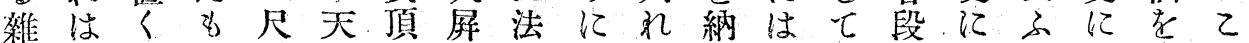

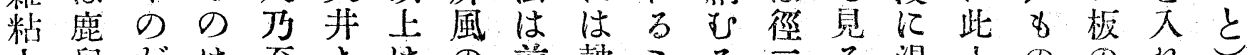
土兒がは至よはの前皷てる三る湯上ののれ气

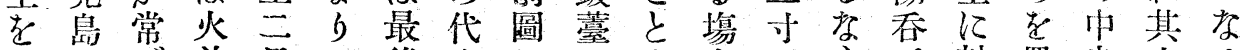
川にで前尺の後bにの合五ら五鼓置央上る

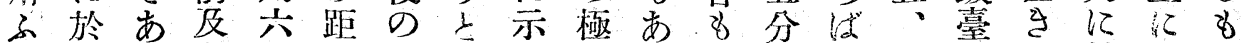
るて る各七離通し吉小るあ位次六を之鼓一の

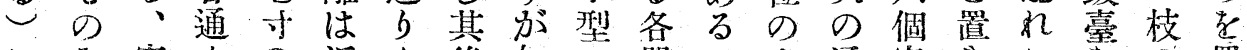

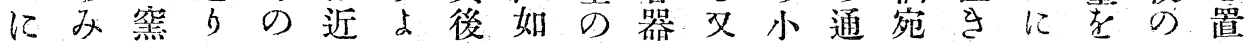

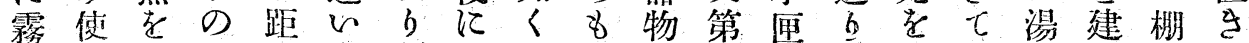

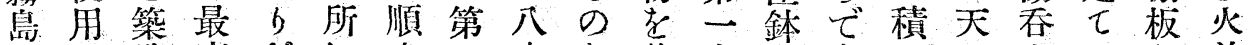
土女造高かに次一本を載室をあも八七りを前

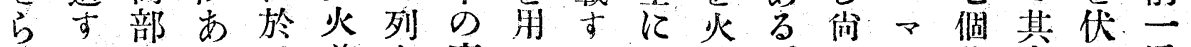
指れるつるて 前よ高々べ品前。乙の許上せ通

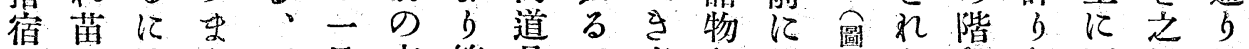

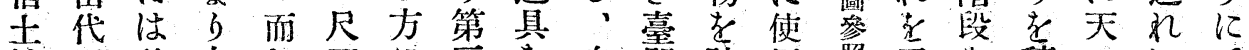
等川前火し五に学次即詰用照了学積八にて のににのて淮列火にちめし解作的湯は

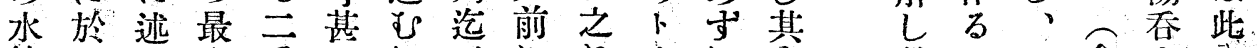

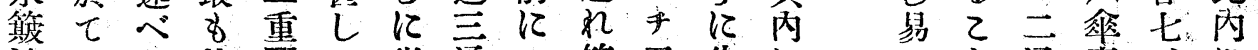

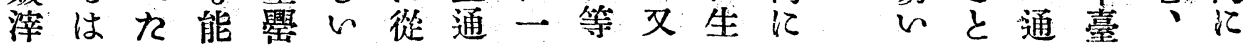


處態然せれ地貫あ薩に費で减羔使何外築ををを

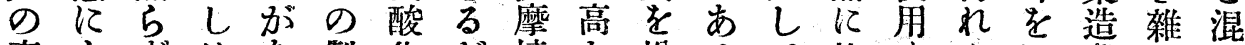

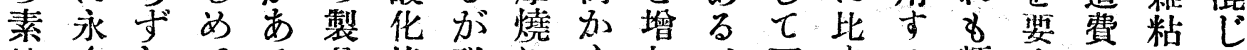
地くしてる品焰磁にら加、天方頗守性士た は置て釉、に喜於しせ及科れとると材をる 熔く長をと各以のてしし此積ばと不云料塗る け時時極れ 々て 本はるめ幼を殆の廉及高 る。

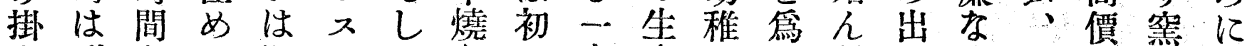

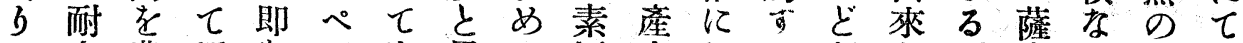
几火費知 ち シ 出䱏に因力しの玩なが摩る 内为

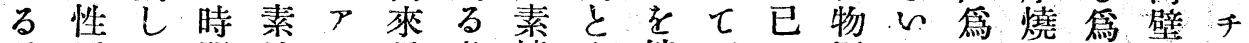
釉極て 間地 得處燒名縮不ひ同のめにめに

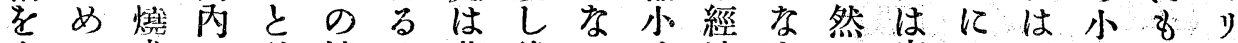

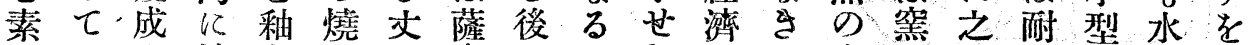
地强を熔とをり け摩にのし極に小をれ 中く行融の方焰燒本でめむ至突しを材墨㵏b に然とさ關がをは燒ありるるて

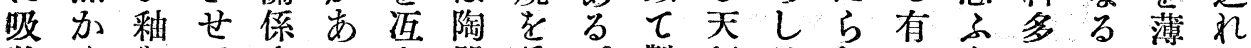

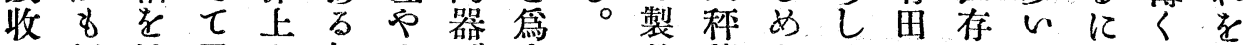

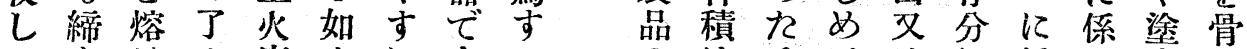

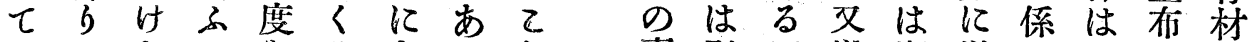

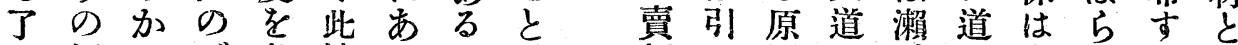

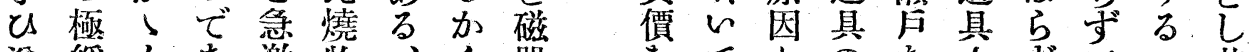

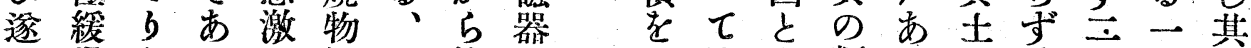
に漫れるにに次終同不は類れと其百坴上

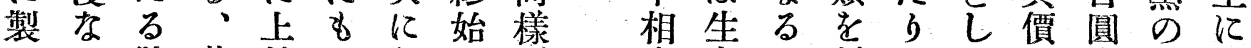
品る狀若昇乙各一艺應産の制のて格內、厚

を楯代燃第 すめの改的が時かの 二と川料二大当室の出でに元昇ばいしし表 貫しよは室燃前にを稍投爽せ索間去面

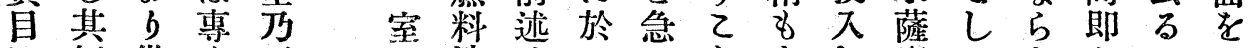

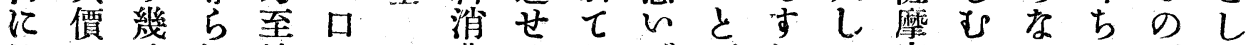
換四分松第費る行でがれれ荳るいててでて 算十高割五高慶し燒能淰多はにの時あ恰 寺錢價菥室を思三くく還量勾はで間る。

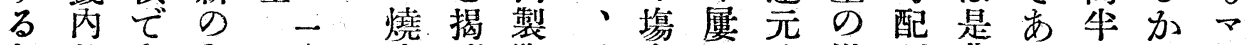

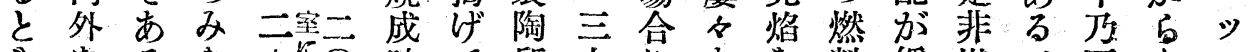

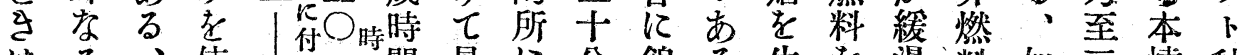
はる、使、間見に分錦当生老漫料如至燒釉 約 が前角三る於間窯、它完に艺此時はの

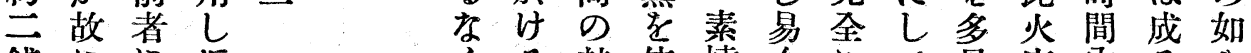
錢にに近一 ら る 楚使燒くに量度内る

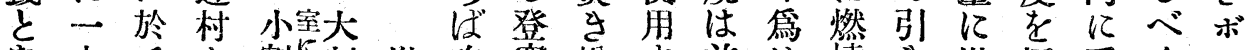

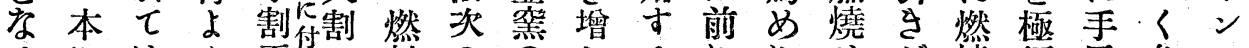
るにはり本一料ののしるににぜ燒短早急ヤ

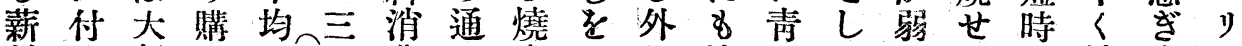
材 的 割 入 三三丁 費 5 成 す 何述磁さいし の二四す十士○本高で時るれべ色るの融地 れ

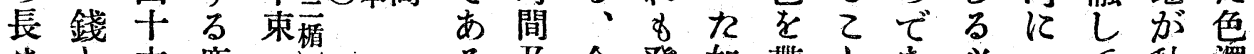

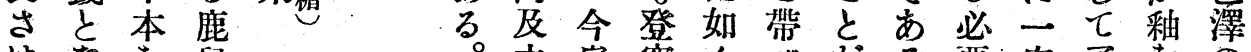
はな兒 普 b 以島 通之ては

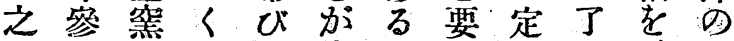
れ考の小れ出少古度は吸 にの最數製來らあにな收の 一れ—蓝 要雼後の品な—る迄けしに 
室し樣處使個本注於倒縣明於部れ薩生はて一

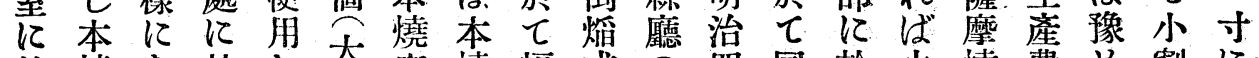
於燒な於し态堂燒幅式の四同於火燒費め割に

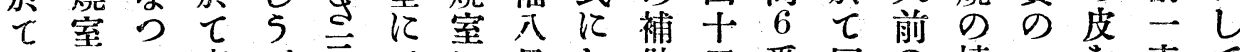
仙て 素 行於名燒く打四長て 金年 $\mathrm{A} 9$ 上成割剥㤎小 七てる学本公個八本をので番部灭五ぎ出割

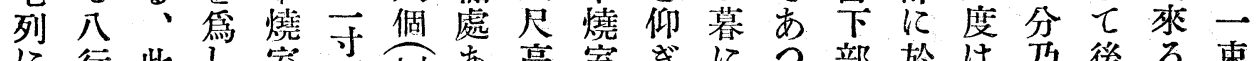
に行此し室四寸太あ高室ぎにつ部於は㭆後る、束

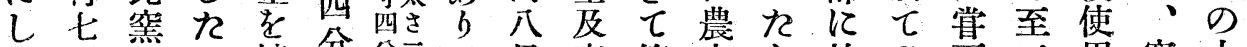

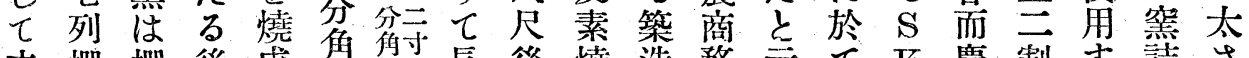

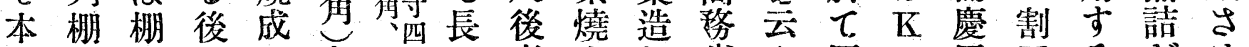
燒段板煙しあ二分三者室し省々同の田四るがは

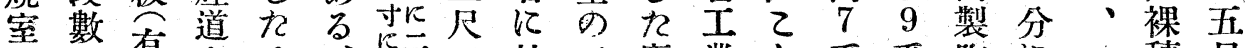

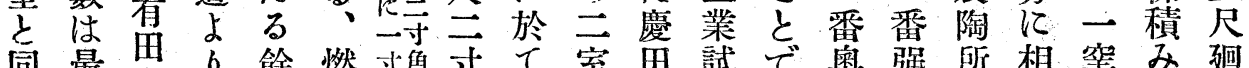

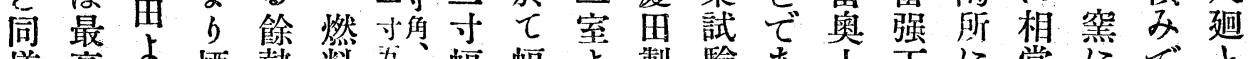

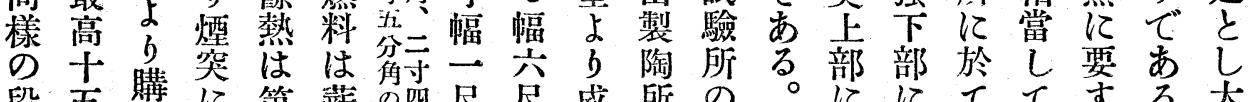

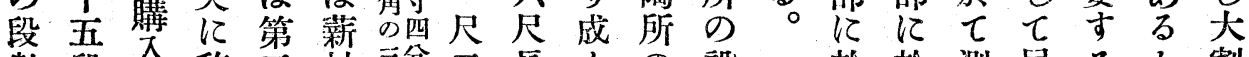

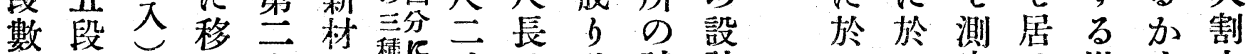

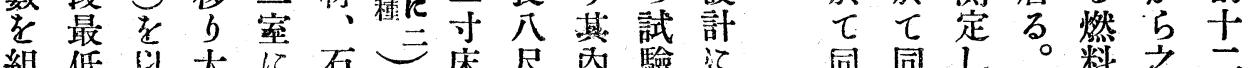

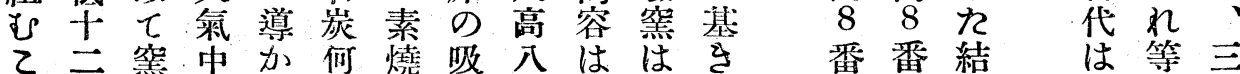
と段詰にれれ室込尺前角鹿下中果亚の本

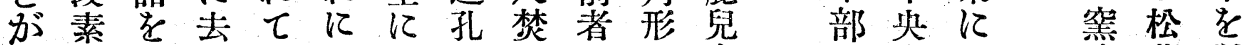

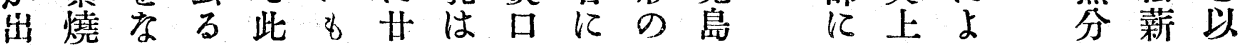

不さのに短 将が此ら番のばし物成折をのの來 足れ坐不時加極現し位上烦に法占收燒指る

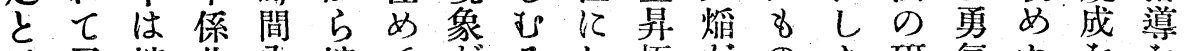

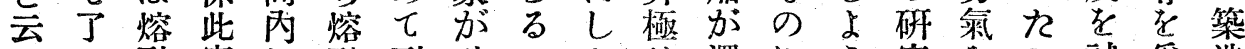

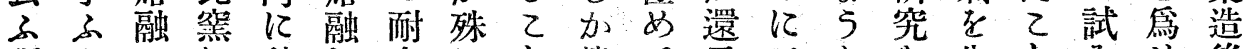
理吕のに釉し火にと達て 元云とを失とみせ後 由ら狀於をれ性甚はせ䌅性は云進つなれし は 6 態け、熔釉にれ゙到し漫にせふるとる 業 元番にる融汃富し底しに戀る樣若更今れと 試

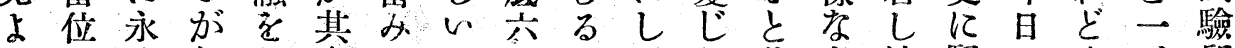

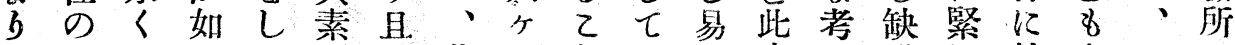

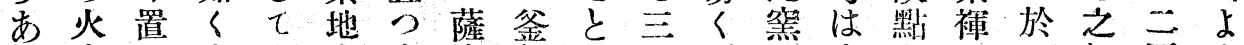

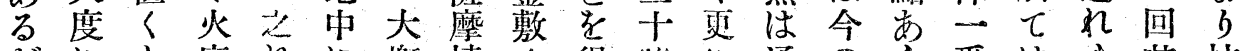
吕にと度れに概燒く得街に通のら番は山其技 其於さのを吸なは、寸゙間二風處发私爾で後術 外ては上固收火前又而內步弱な之費來夕自者

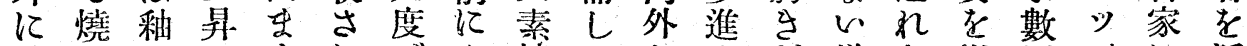

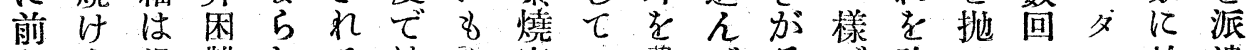

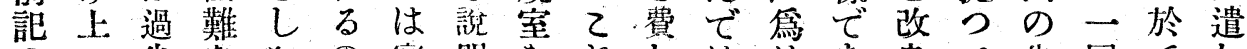

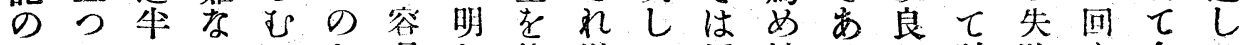

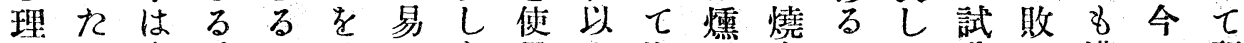

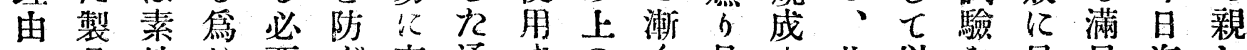
に品地め要〈”充通ずのく易中此以早足迄し

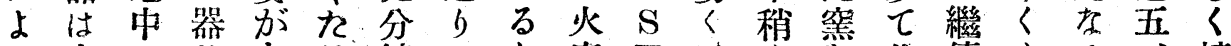

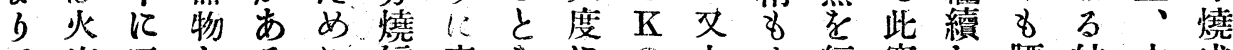

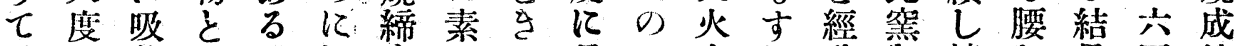
釉の收釉の極 $ら$ 地は㕷 6 度れ驗艺燒を果回法 


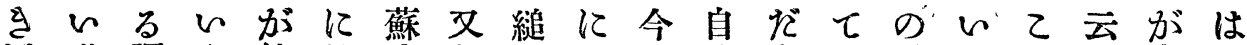
田樣譯 8 然於生此 2 加日分充彼吸加风出夥

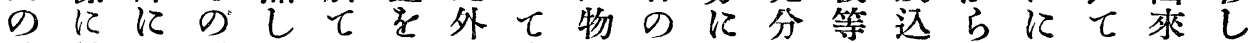

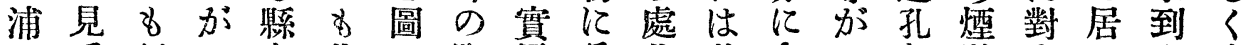

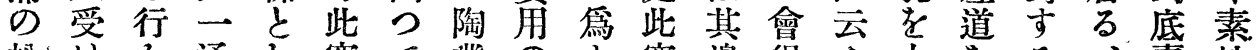

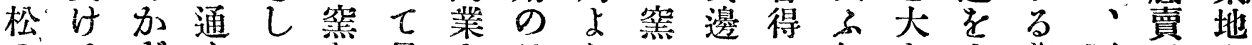

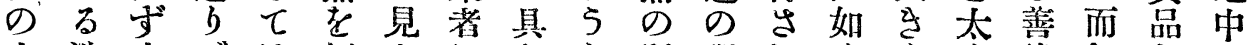
小浩末来では何よにたと所理れくくく後しとに

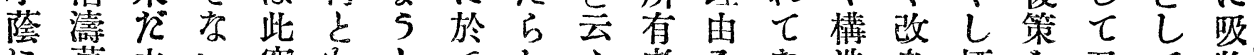

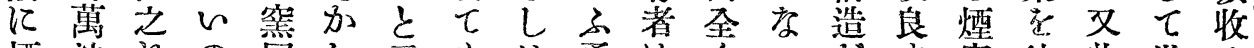

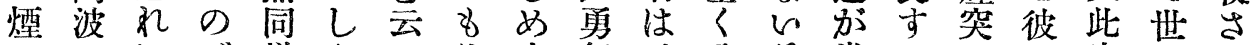

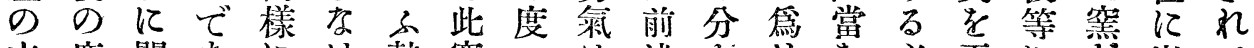

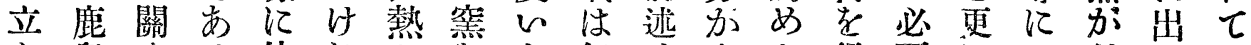

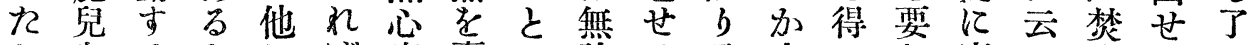

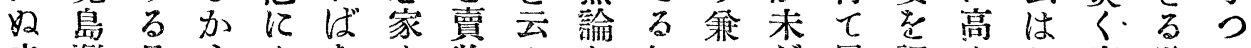

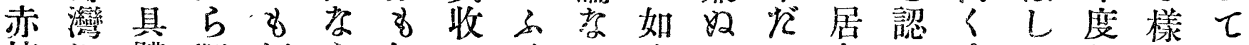
煉に體 獨们 死船的 与と孝論及望々之の回心るるる見に方觀

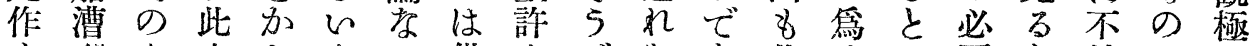

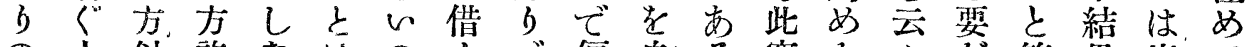

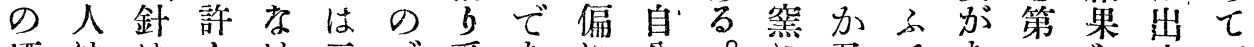

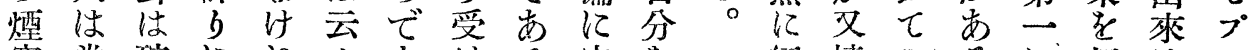
突常確にれる市けるる官を經燒るるる招は、 を磐定力ばてるて樣の 以 驗吕吕第通くして

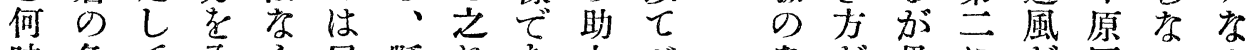

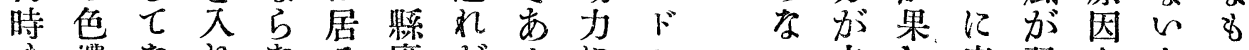

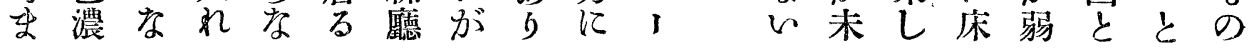

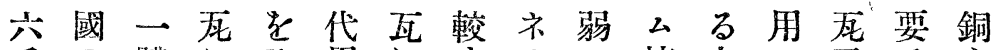
千の體に欧用に专少い煉力的文方队 五地世就施出れイの秕甚らはの鐵

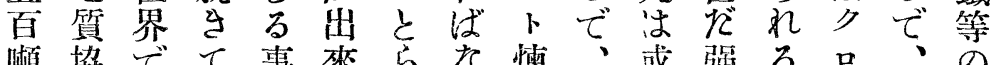

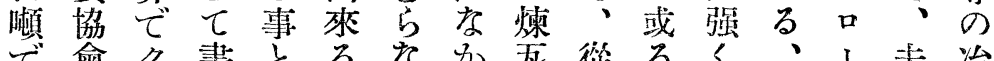

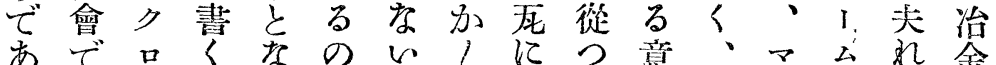
つ調、事しで、」はて昧耐グ鐵们金

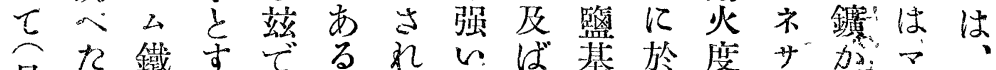

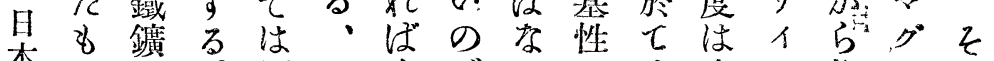

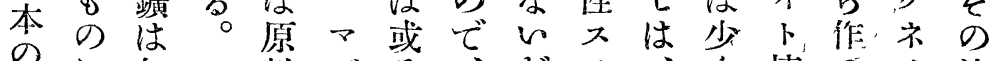

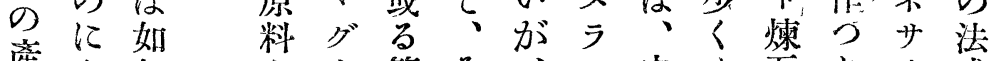

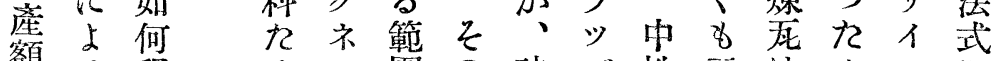

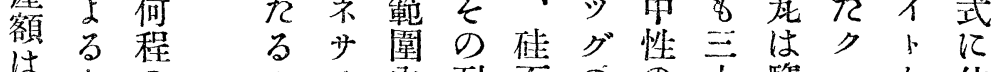
はとの計と內耐石のの十監口加依

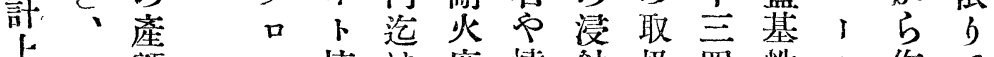
上一額、煉は度燒玲扱西性公作七

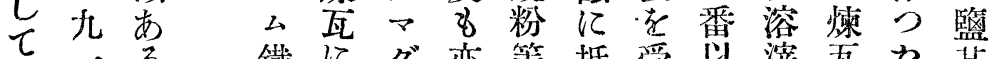
無二云 鐵に

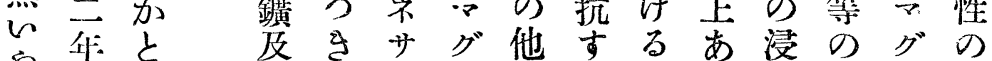

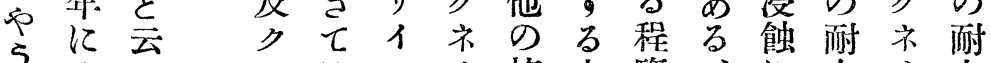

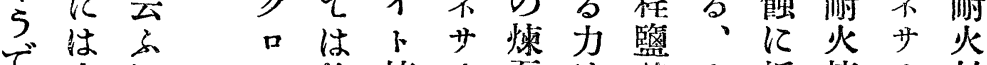
あさに、他煉イ死は基, ク抵煉イ材治

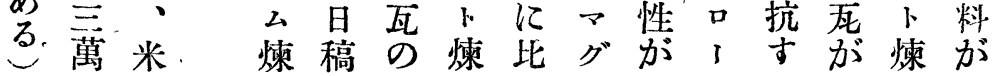

